\title{
Delivering Justice for Women Victims of Conflicts: How Judicial Mechanisms Perpetuated Gender Inequality in Timor-Leste
}

\author{
Sorang Saragih \\ UN-mandated University for Peace, Costa Rica
}

\section{Mita Yesyca}

Universitas Kristen Indonesia, Jakarta

\begin{abstract}
Abstrak: Timor-Leste adalah salah satu kisah sukses operasi perdamaian Perserikatan Bangsa-Bangsa (PBB) terlepas dari lamanya operasi tersebut dilakukan. Intervensi $P B B$ di Timor-Leste bersifat khusus karena PBB menetapkan dua mekanisme peradilan selama operasi perdamaian berjalan, yaitu Serious Crime Unit (SCU) atau Unit Kejahatan Serius dan Komisi Kebenaran (CAVR). Baik SCU maupun CAVR memiliki mandat yang berbeda dengan tujuan bersama untuk mengatasi pelanggaran HAM yang terjadi di Timor-Leste. Tulisan ini bertujuan untuk mengkritik kedua mekanisme tersebut, khususnya mengenai bagaimana inisiatif ini mengusahakan keadilan bagi perempuan korban konflik di Timor-Leste. Kritik berfokus pada mandat, tindakan dan otoritas mereka. Berdasarkan ketiga aspek ini, kesimpulan yang dihasilkan adalah mekanisme -mekanisme ini gagal memberikan keadilan bagi para perempuan korban di Timor-Leste.
\end{abstract}

Kata Kunci: Timor-Leste, operasi perdamaian PBB, pelanggaran HAM, mekanisme peradilan, SCU, CAVR, perempuan korban

Abstract: Timor-Leste is one of few success stories of the United Nations (UN) peacekeeping operations despite its long period. The UN intervention in Timor-Leste is unique because it established two justice mechanisms during the peacekeeping operations, namely the Serious Crime Unit (SCU) and the Truth Commission (CAVR). Both SCU and CAVR have different mandates with a common objective to address human rights violations committed in Timor-Leste. This paper tries to criticize these two mechanisms, particularly on how these initiatives delivered justice for women victims of conflict in Timor-Leste. The critique focuses on their mandate, performance, and authority. Based on these three aspects, it is concluded that these mechanisms failed to deliver justice to women victims in Timor-Leste.

Key Words: Timor-Leste, UN peacekeeping operation, human rights violations, justice mechanism, SCU, CAVR, women victims 
Korespondensi Penulis:

Sorang Saragih, Gender and Peacebuilding Program, UN-mandated University for Peace (UPEACE), Costa Rica.

E-mail: sorang.saragih@gmail.com

Mita Yesyca, International Relations Study Program, Universitas Kristen Indonesia (UKI), Jakarta.

E-mail: mita.yesyca@uki.ac.id

\section{Introduction}

Conflict-affected and conflict risk areas are usually marked by the presence of armed conflict which inflicts harm on people. In those areas, a confrontation between one or more parties might occur repeatedly. They result in the experience of direct violence by people in the region. Meanwhile, in areas where open warfare has come to an end, the situation of the affected community sometimes has not changed much: people suffer from structural violence that continues exists after the conflict has ended. This unrecovered harm from the conflict will, in turn, prevent the community from functioning and developing properly afterward.

Not all conflicts, indeed, result in destruction. If it is managed constructively, a conflict will develop many aspirations without producing violence. However, most conflicts face difficulties in finding a lasting solution due to many constraints. Instead of getting solved, violence or war is very likely to appear following a conflict. In Indonesia, there are quite a number of regions experiencing this kind of situation and if it is not addressed well; an armed conflict will always continue to emerge.

In such circumstances above, women are the most vulnerable to suffer from violence. Both women who are victims of conflict and those who are associated with the conflicting parties are very likely to be the target of violence because of societal genderbased inequalities. This article is trying to discuss the approach to conflict-affected 
areas carried out by an organization that is well-known for its experiences-though sometimes its authority and legitimacy are questioned-to act in the midst of such conditions, namely the United Nations (UN).

Devastated by armed conflict, an area can be impoverished; but the recovery of infrastructure and socio-economic systems is not the only task of post-conflict authorities to restore community functions as before. The restoration of damaged social relations, including its norms, and the prevention of recurring armed conflicts are the prerequisite for the stability of post-conflict societies. This paper offers a description of the importance of those specific conditions of conflict risk areas ${ }^{1}$ and the impact of policies implemented afterward. In particular, special attention is given to women victims and their conditions in post-conflict settings based on the aforementioned aspects.

A lot of literature has helped in building an understanding of women in conflict and post-conflict areas, especially studies from the UN that gave recognition to the roles and experiences of women in conflict risk areas. In this paper, the discussion is limited to some studies related to the recovery approach to conflict risk areas. These studies were born after the presence of global evidence of so many conflicts and wars as well as the emergence of new countries from the conflicts. These two factors contribute to the development of research agenda on peace and post-conflict recovery.

\footnotetext{
${ }^{1}$ We do not separate the terms exclusively here, both post-conflict and conflict risk areas. We think that without comprehensive handling, a conflict that has ever arisen will always at risk of reappearing. Another approach which is more productive is by seeing such situation as a process that involves a number of peace milestones, i.e.: (1) cessation of hostilities and violence; (2) signing of political/peace agreements; (3) demobilization, disarmament, and reintegration; (4) refugee repatriation; (5) establishing a functioning state; (6) economic recovery; (7) and making significant progress towards reconciliation and societal integration (Brown in Langer, Stewart and Venugopal 2012,3). Using this approach, a country or an area 'should be seen as lying along a transition continuum (in which they quite often move backward), rather than being placed in more or less arbitrary boxes labelled 'in conflict' or 'at peace" (Brown in Langer, Stewart and Venugopal 2012, 3).
} 
The first literature is Sultan Barakat and Steven Zyck's (2009), titled “The Evolution of Post-conflict Recovery". They followed and studied the development or 'evolution' of post-conflict recovery practices. According to them, there are three primary phases of post-conflict recovery approach between the 1970s and 2001 . Barakat and Zyck also conducted an analytical history of major conceptual and practical innovations in post-conflict programs. They looked at 1) the primary sectors of activity; 2) the critical or emerging actors; 3 ) the aims, objectives and final beneficiaries; and 4) the relative emphasis put upon recipient state institutions and their relation to international actors (Barakat and Zynk 2009, 1073).

The Cold War made the phase I of post-conflict recovery with macroeconomic liberalization and democratization through Structural Adjustment Programs (SAPs) as the dominant elements. The failure of SAPs, which civil society groups considered to marginalize the most vulnerable groups and prioritize elites, then made the recovery approach shift to people-centered ones. This approach also raised a new form of partnership between international organizations, donor agencies, recipient governments, and 'grassroots' civil society.

The loss of Cold War tension and the weakening support for states' sovereignty characterized the presence of Phase II. In many countries, the demand for autonomy and self-determination emerged after the state power was weakened. The weak power of states to control its people and territory encouraged outside interventions; but on the other hand, post-conflict recovery activities became increasingly broad and deep the first time. The UN peacekeeping operation introduced the disarmament, demobilization, and reintegration (DDR) of former combatants and various other aspects of security sector reform (SSR) as core activities in post-conflict contexts. Most activities, however, remained under the control of growing NGOs which began to intervene in the social 
dynamics, particularly with regard to inter-group and inter-ethnic relations and gender in the name of peacebuilding and social equity.

Democratic approaches of the interventionist recovery were then questioned. Along with the decreasing role of recipient states, the question of 'good governance' rose in prominence and intervention was seen with skepticism. This criticism led to a phase III of post-conflict recovery. A strong emphasis was put upon collaborative governance involving the recipient state, local civil societies and, least importantly, the international community when a learning process is used. Rather than invite individuals from conflict-affected countries to engage in foreign-led processes, the international post-conflict recovery establishment ought to be requesting permission to support a locally owned process (Barakat and Zynk 2009, 1076).

After the 9/11 terrorist attack, scholarships and practices regarding post-conflict recovery have brought entirely new categories of actors, objectives, and activities. Barakat and Zynk's research has contributed to showing the international politics of post-conflict practices and concluded that approaches to post-conflict areas are still not final and continue to develop. The latest trend shows that recovery is left to the local community's readiness to recover and manage the process so that conflicts do not recur.

The second literature is Horizontal Inequalities and Post-Conflict Development (2012). The book investigates whether and how horizontal inequalities are being addressed in post-conflict situations and what impact this has had on eight post-conflict countries: Burundi, Rwanda, Nepal, Peru, Guatemala, Bosnia and Herzegovina, Afghanistan, and Uganda. 'Horizontal inequalities' refer to severe inequalities between culturally defined groups, whose identities can readily be used for political mobilization. The horizontal inequalities can be economic-inequalities in access to and ownership of assets; social-inequalities in access to a range of services; political-inequalities in the 
distribution of political opportunities and power; and cultural status-disparities in the recognition and standing of different groups' languages, customs, norms, and practices (Langer, Stewart and Venugopal 2012,6).

The research confirmed that one of the major causes of conflicts was the inadequate recognition from states and international actors on horizontal inequalities. It was seen from the weaknesses in institutional design and state capacity, and the growth of sources of economic prosperity that directly or indirectly benefited some (usually richer) parts of society disproportionately. Although there are countervailing policies in the conflict risk areas; yet policy towards addressing horizontal inequalities in the cases studied has been very limited. Horizontal inequalities have been taken into account in the government' recovery policies, but elite interests often influenced the way they were addressed. Langer, Stewart, and Venugopal, thus, have shown that it is crucial to include policies that address horizontal inequalities properly to reduce the likelihood of their recurrence.

Both of the above literature shows that the UN has implemented many postconflict approaches, both in research agendas and practices. This paper seeks to look further on the UN initiatives to take insight from its experience in handling conflict risk areas. It is hoped that this insight can contribute to the betterment of future approaches taken in future in conflict risk areas, not only by the UN, but also for other actors.

\section{Concepts}

There are some terms to refer to the UN activities in maintaining international peace and security. These terms are interrelated in their aims and practices. The UN Peacekeeping Operations, in principle, deployed to support the implementation of a ceasefire or a peace agreement. They are often required to play an active role in 
peacemaking efforts and may also be involved in early peacebuilding activities (UN Peacekeeping n.d.). 'Peacemaking' is understood as activities that include measures to address conflicts in progress and usually use diplomatic actions to bring the confronting parties to a negotiated agreement. The implementing actors of peacemaking are not only governments or governments' coalitions, such as the UN, but also unofficial and non-governmental groups, or prominent personalities working independently (Whitfield \& Griffiths, 2010, March).

If the conflicting parties have ended their actions, there is a need to reduce the risk of conflict recurrence by strengthening national capacities at all levels for conflict management. This 'peacebuilding process' takes place in the long run. It must lay the foundation for sustainable peace and development in conflict risk areas. One of the central things to build sustainable peace is solving the root causes of conflict. Efforts to overcome inequality among people are usually done in a top-down process. Those are good for preventing recurrence of conflict, but not necessarily succeed in curing the effects of violence in conflict. Thus, the people-centered approach serves as an alternative by bringing the concept of 'restorative justice'. This concept arises due to the dissatisfaction of the retributive justice system that emphasizes the punishment for the guilty party. Evidence has shown that punishment alone is not effective in changing behavior and, sometimes even, disruptive to community harmony (Conflict Solutions Center n.d.). Thus, restorative justice presents to shift the focus of recovery to ending the legacy of past injustice through problem-solving and negotiating obligations for each party in the future (Conflict Solutions Center n.d.).

Another useful concept for analyzing post-conflict recovery is 'patriarchy.' It has been explained that the types of actors involved in the recovery process, in identifying, and later in revoking the roots of conflict are very decisive on the characters of peace in 
conflict risk areas; whether it will be sustainable or not. Women are often not recognized and involved in collective decision-making processes in the community and patriarchy has something to do with this. As Slyvia Walby (1991) has defined, patriarchy is a system includes social structures and practices in which men dominate women. Some manifestations of patriarchy can be seen in the superiority of men in the family and the recognition of descent and inheritance according to the male line. As a system of social relations, the practices of patriarchy can also be identified in many settings, including in post-conflict recovery activities.

\section{The UN Peacekeeping Operations in Timor-Leste}

Timor-Leste is one of few success stories of UN peacekeeping operations despite its long period (UN n.d.a). Since 1999, the UN had participated actively in promoting peace in this area through many forms, starting from the establishment of UNAMET (United Nations Mission in East Timor) as a civil administration in June 1999 to hold a referendum to decide for staying under Indonesia or becoming an independent state. UNTAET (United Nations Transitional Administration in East Timor) came afterward as a peacekeeping operation and a transitional administration in October 1999 until its independence in May 2002. UNMISET (United Nations Mission of Support in East Timor) came to replace UNTAET as a peacekeeping operation in May 2002. After UNMISET had finished its period, UNOTIL (United Nations Office in Timor-Leste) operated in Timor-Leste in May 2005 as a political operation to support its statebuilding process. When the crisis occurred in the country in 2006, UNMIT (United Nations Integrated Mission in Timor-Leste) came in August 2006 as a peacekeeping operation to end the crisis and ended its service in December 2012 (UN n.d.b). 
What made the UN intervention in Timor-Leste unique is its initiative to establish two justice mechanisms during the peacekeeping operations, namely the Serious Crime Unit (SCU) and the Truth Commission (CAVR). This initiative derived from a consideration that the concept of a classical peacekeeping operation is not enough to address conflict, particularly when it required a comprehensive conflict resolution measures due to its complexities (Bureš, 2006). Both SCU and CAVR came as two justice mechanisms with different mandates used to achieve a common objective to address human rights violations committed in Timor-Leste.

This section aims to criticize these two mechanisms, particularly on how they delivered justice to women victims of conflict in Timor-Leste. The critique focuses on their mandates, performances, and authorities. Based on these three aspects, it is concluded that these mechanisms failed to deliver justice for women victims in TimorLeste. In this part, the terms "Timor-Leste" and "East Timor" refer to the same area. The different name only aims to show the different periods; East Timor is before its independence and Timor-Leste is after its independence.

\section{Discussions}

\section{Justice Mechanisms: SCU and CAVR}

The widespread human rights violations in East Timor after the referendum motivated the UN Security Council to use its authority under Chapter VII of the UN Charter to establish UNTAET as a peacekeeping operation in the area through the Resolution 1272. The resolution mandated UNTAET to take all necessary measures to restore peace and security in East Timor until its independence in 2002, including to bring the perpetrators of the violence in East Timor to justice (UNSC Resolution 1272, 1999). Accordingly, UNTAET established the Serious Crime Unit (SCU) in 2000 with a specific 
mandate to investigate serious crimes (genocide, war crimes, and crimes against humanity) committed in East Timor in 1999 and to prosecute the perpetrators in a hybrid court consisting of two international judges and one East Timorese judge (Serious Crime Unit n.d.). SCU completed its investigations in November 2004 and ended its operation in May 2005.

To complement the work of SCU, UNTAET also established an independent truth commission named Comissão de Acolhimento, Verdade e Reconciliação de Timor Leste or Commission for Reception, Truth, and Reconciliation (CAVR) in 2002. Different from SCU, CAVR was mandated to conduct an inquiry on ordinary crimes committed in East Timor in 1974-1999 and to promote the re-integration of the criminals in the community with no authority in conducting judicial measures (Hirst \& Varney, 2005, June). CAVR led the re-integration through truth-telling and reconciliation processes (Grenfell, 2013). As highlighted in its name, CAVR "receive" the perpetrators through a local tradition called nahe biti, translated as rolling the mat (Pigou, 2004, April). Both the perpetrator and the victim were invited to sit on a mate encircled by the community. The perpetrator then told all his violence and asked forgiveness from the victim. When the victim granted the forgiveness, the perpetrator was then received back in the community. This process is a way for CAVR to uphold restorative justice in the community.

CAVR has no authority of serious crimes, so it had to refer the cases to SCU, but only limited to 1999. These specific mandates made both UN justice mechanisms unable to investigate all serious crimes committed in 1974-1998 nor to bring the perpetrators to justice. CAVR still recorded all serious crimes that happened before 1999, but the perpetrators were not granted amnesty as the ordinary criminals. The record only functioned as an archive that the government of Timor-Leste could be used in the future 
for further investigations. The differences between SCU and CAVR are summarized in Table 1.

Table 1. Differences between SCU and CAVR

\begin{tabular}{|c|c|c|}
\hline Aspects & SCU & CAVR \\
\hline Period of work & $2000-2005$ & $2002-2005$ \\
\hline Scope of work & Serious crimes in 1999 & Ordinary crimes in 1974-1999 \\
\hline Given authority & $\begin{array}{l}\text { Investigation and } \\
\text { prosecution }\end{array}$ & Inquiry \\
\hline Designed approach & Judicial measures & Reconciliation measures \\
\hline
\end{tabular}

\section{Flawed Mechanisms: The Incompetent SCU and the Trifling CAVR}

Despite its strong mandate and narrow scope of work, SCU could not deliver a satisfactory result due to its limited capacity. In their report, Hirst and Varney (2005, June) described the limitations. In its early period, most of the SCU's indictment only involved charges of murder rather than charges of serious crimes, such as crimes against humanity or war crimes. It was suspected that SCU did that to reduce the time and cost of trials. SCU had tried to move toward the indictment of crimes against humanity in mid-2001, but its limited numbers of staff members stopped this good step (Hirst \& Varney, 2005, June). It was reported that SCU had 124 members in 2003, but it was then significantly reduced afterward, particularly on the number of investigators, leaving only 74 members in 2005. More than that, SCU also had a lack of international judges, causing the court failed to conduct any trial since the end of October 2001 until June 2003. 
The short notification of the UNSC in May 2004 further worsened the condition. It instructed SCU to finish all investigation by November 2004 and to suspend all activities by May 2005. This situation left SCU with fewer options to deal with the cases. SCU then decided to focus only on ten prioritized cases with all cases involving murder. SCU only investigated rape or other cases when those were related to murders (Hirst \& Varney, 2005, June). This decision automatically discriminated the women victims because their suffering was valued as less important to be counted as serious crimes. For SCU, the death of women victims in the conflict because of their powerlessness was more important than their strength to defeat the violations and to stay alive. Women's mortality was turned into an act of heroism, unlike their lives.

In total, SCU managed to issue 280 arrest warrants. However, it still held the warrant for General Wiranto who was supposed to be held accountable due to his position as the commander of Indonesian soldiers in East Timor in 1999 (ETAN, 2005, May 26). He was not apprehended and this decision ignored the principle of impartiality in upholding the justice. SCU also managed to produce 95 indictments involving more than 350 persons, mostly with in absentia status because they had fled to Indonesia. The majority of these persons were Timorese pro-Indonesia militias with few high-ranking Indonesian military commanders. SCU could not chase them to Indonesia because the government refused to permit SCU to do that. The lack of consent from the government of Indonesia eliminated any possibility for SCU to adequately perform its mandate, showing that the state's consent remained a major obstacle in the UN peace operation (Doyle \& Sambanis, 2015). Responding to this situation, SCU chose to stop taking further actions to prosecute those perpetrators who remained in Indonesia by stating that "they reside outside of our jurisdiction" (Siboro, 2006, February 22, para. 4). 
Of all indictments, only eight involved gender-based crimes. Six of them were for rape as a crime against humanity (not as a war crime) and only one of the six cases went to trial. This situation resulted in the only conviction for rape as a crime against humanity (AJAR, 2013). On one side, this conviction became a major achievement because it was the only recognition of rape as a crime against humanity in the AsiaPacific region in the previous decade (AJAR, 2013). However, on the other hand, the fact that there was only one conviction reaffirmed the fact that the experience of women victims did not receive equal attention in the justice measures. Even worse, SCU never charged sexual slavery and other types of gender-based violence, or any similar violations committed before 1999. This decision was taken although many reports and publications have highlighted the occurrence and severity of these crimes, including the final reports of CAVR. It implied that gender-based crimes, except for rape, was not recognized as serious crimes and that women's experiences of violence in Timor-Leste were considered as less important to men's experience.

The limited number of staff members result in not only the selective cases put on trial, but also the undistributed information on the verdict and its implementation. This situation contributed to exacerbating the injustice in the society, particularly against women victims. Angela Soares, whose courageous confession led to the only conviction of rape as crimes against humanity said that she was not informed about the court's verdict for two years (Wandita et al., 2015, October). Juvita Saldanha, whose daughter had been tortured to death, only knew that the perpetrator was sentenced to eight years in jail with no clear information whether he was put in jail or is still free (Wandita et al., 2015, October). Similarly, Agripina dos Santos had testified in the court on her husband's killing, but she did not receive any information on the progress of the case (Wandita et al., 2015, October). 
It is said that CAVR provided another alternative for upholding justice for victims due to its broad scope of work. However, this was not true and even deepened the denial of women victims' equal rights. Choosing CAVR instead of SCU in dealing with violations experienced by women victims degraded the equal importance of women's experience with men's experience. CAVR only dealt with ordinary crimes, so the decision to process the cases to this mechanism would eliminate any possibility for the recognition of other forms of gender-based violence outside rape as a serious crime. Furthermore, the approaches of CAVR also closed any opportunity for judicial measures and legal recognition as it only used one approach, namely reconciliation. CAVR could not push perpetrators to go on trial regardless of the severity of their violations once the case had been decided as an ordinary crime. In other words, the reconciliation approach only further perpetuated impunity in Timor-Leste. It was a major setback in Timor-Leste amid international progress on the advancement of women's rights, especially after the adoption of Resolution 1325 on Women, Peace and Security in October 2000 that underlined the need to abolish amnesty provision in gender-based crimes (Dam, 2013).

It is argued that CAVR still provided an opportunity to upgrade the level of importance of a case from "ordinary crime" to "serious crime" by submitting it to SCU. However, it was less likely for SCU to prosecute the case due to its lack of staff members and lack of available time between CAVR's notification and the termination of SCU's work, considering that CAVR started its work much later than SCU. Another option was putting the case in the report of CAVR so that the government of Timor-Leste could use the case for further investigation and prosecution, but this was less likely to happen too, as explained below. 
Picture 1. Male protesters against the work of the SCU in Timor Leste

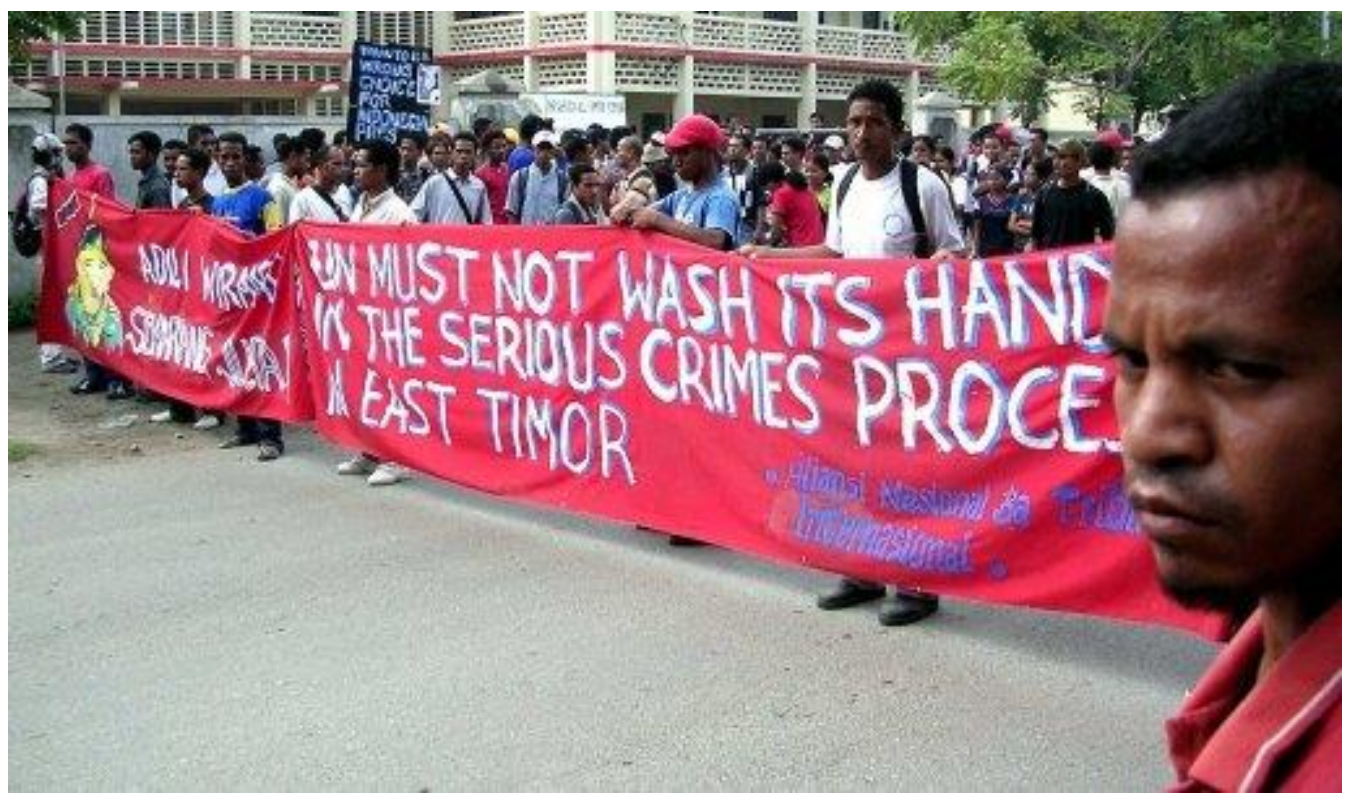

Source: La'o Hamutuk (2004)

\section{Failed Mechanisms: When the Government of Timor-Leste Said "No"}

Despite its relatively short period of work compared to SCU, CAVR could collect much more information on human rights violations committed in Timor-Leste. From its research, CAVR managed to document more than 18,500 murders and disappearances and discovered that more than 8,300 people died from health problems during the displacement and forced-settlement. From its national public hearings, CAVR documented more than 5,000 illegal murder, more than 800 disappearances, and 60,000 other violations, in which around 800 cases of them, were sexual gender basedviolence consisting of rape, sexual slavery, forced contraception and abortion (Wandita et al., 2015, October). Similar with SCU, CAVR also recognized that rape was a crime against humanity in 1974-1999. 
CAVR had published its report into five-volume books with a total of more than 2,000 pages. The report contained some recommendations, including suggestions to the government of Indonesia to uphold justice for human rights violations committed in East Timor in 1974-1999 (Elsanti, Isaiyas, \& Walsh, 2013, November). The report had been handed over to Timor-Leste President Xanana Gusmao in 2005, but victims did not receive justice either because the government of Timor-Leste had decided not to hold the perpetrators mentioned accountable in jail. A year before the report was submitted, President Gusmao and Indonesian President Megawati Soekarno Putri agreed to deal with the human rights issues through reconciliation approaches rather than judicial measures (Asia Intelligence Wire, 2004, May 18). Similarly, before the UN Security Council and Human Rights Commission in 2005, Timor-Leste Foreign Minister José Ramos-Horta also stated that "Timor-Leste needs "restorative justice" focused on the future, rather than "retributive justice" focused on prosecution, punishment, and the past" (Hirst \& Varney, 2005, June, p. 28).

Acting as the Timor-Leste president in 2009, Ramos-Horta showed the same stance again by reiterating that Timor-Leste had received its greatest justice in the form of independence. Thus, he reiterated that the country had closed the memory of 19751999 and instead, focused on building a good relationship with Indonesia to support its national development (Iliopoulos, 2009). The combination of a firm objection of the Timor-Leste government and a strong refusal of the Indonesian government to address the human rights violations effectively shut down the UN good initiatives to deliver justice for victims in Timor-Leste. This reality once again proves that the main principle of the UN to rely on states' consents as a symbol of their sovereignty has been a substantial blocking rock to uphold justice for victims in Timor-Leste. 


\section{Conclusion: Justice Remains Elusive for Women Victims in Timor-Leste}

The stories of the UN Peacekeeping Operations in Timor-Leste have been remembered as a successful intervention of an international organization in making peace in a state. The UN proactively took initiatives to ensure the new state could sustain in its postconflict recovery, including by delivering justice to its affected people through the establishment of SCU and CAVR in 2000 and 2002 respectively. This paper has shown that the justice delivered by these two mechanisms in Timor-Leste's context of postconflict recovery was in fact, favored the elite and perpetuated horizontal inequalities in the community, particularly against the women victims.

The internal weaknesses of both SCU and CAVR, derived from its lack of resources and its flawed main principle to prioritize states' consents above all aspects, eventually drag them to a hollow of failure. SCU presents with a stronger authority than CAVR to bring the perpetrators of human rights violations to be accountable. However, it failed to take a fair and impartial action in implementing its mandate, undermined the violations against women survivors, and further exacerbated the injustice in the society. CAVR as an alternative justice mechanism came to serve restorative justice for the victims. However, it eliminated any possibility for women victims to bring their cases to a judicial system as it promoted reconciliation that was followed by the granting of amnesty to the perpetrators.

Moreover, the lack of states' willingness to bring the perpetrators to be accountable for their crime further unable the women victims to get the justice they deserve. Thus, the women victims of conflict in Timor-Leste only received cheap justice from the UN in the form of powerless indictments, impotent arrest warrants, an unclear end, and a weak public recognition on what happened in the past. Rape was recognized as a crime against humanity in the history of Timor-Leste, but women victims only 
received a cheaper justice from the UN because their sufferings due to their status as women were not considered as equal as of men. In the end, the justice mechanisms from the UN would only contribute to perpetuating impunity and gender inequality in this new state.

The case of Timor-Leste reflects the need to strengthen the UN Peacekeeping Operations and the justice mechanisms it created to be able to create a sustainable peace for everyone. It could be done using a bottom-up approach through negotiations with all groups involved in the conflict and understanding the situations in the field. Putting people's hope for justice only in the state's determination will only give false hope for victims, particularly women victims, regardless of how progressive the efforts can be. A strong mandate for a peace operation will not be enough to make a significant change if it is not complemented with appropriate resources, a powerful authority beyond state's consent, and an equal perspective for both men and women in performing the duty. In the end, the story of the UN success on its peace operations in Timor-Leste was mere a victory for the elites, not the ordinary people who have to continue living with pain from the past and therefore present.

\section{Bibliography}

Asia Justice and Rights (AJAR). 2013. Remembering my beloved, remembering my pain: Victims of atrocities collect photographs and stories to push for change. Jakarta: AJAR.

Asia Intelligence Wire. 2004, May 18. "Wiranto thankful about result of MegawatiXanana meeting." Retrieved from http://www.etan.org/et2004/may/1521/18wiran.htm.

Barakat, Sultan and Steven Zyck. 2009. "The Evolution of Post-conflict Recovery." Third World Quarterly 30(6): 1069-1086.

Bureš, 0. 2006. UN peacekeeping on the 21st century: A capabilities-expectations gap analysis. Czech Journal of Political Science, 379-398. Retrieved from Central and Eastern European online library. 
Dam, M. 2013. Women, peace and security: A feminist critique of UN Security Council Resolution 1325. Human Rights Defender 22(1): 11-13.

Doyle, M., and N. Sambanis. 2015. Peacekeeping operations. In S. Daws \& T. G. Weiss (Eds.), The Oxford handbook on the United Nations (pp. 1-20).

Elsanti, R., I. Isaiyas and P. Walsh. 2013, November. Ed. Chega! The final report of the Timor-Leste commission for reception, truth and reconciliation (CAVR): A plain guide. Jakarta: Gramedia.

ETAN. 2005, May 26. Report to the Secretary-General of the commission of experts to review the prosecution of serious violations of human rights in Timor-Leste (the then East Timor) in 1999. Retrieved from http://etan.org/news/2005/06exec.htm.

Grenfell, L. 2013. Promoting the rule of law in post-conflict states. Cambridge: Cambridge University Press.

Hirst, M., and H. Varney. 2005, June. Justice abandoned?: An assessment of the serious crimes process in East Timor. New York: ICTJ.

Iliopoulos, K. 2009. East Timor ten years on: Justice denied. Retrieved from http://www.crimesofwar.org/commentary/east-timor-ten-years-on-justicedenied/.

Langer, Arnim, Frances Stewart and Rajesh Venugopal. 2012. "Horizontal Inequalities and Post-Conflict Development: Laying the Foundations for Durable Peace." In Arnim Langer, Frances Stewart and Rajesh Venugopal, ed. Horizontal Inequalities and Post-Conflict Development. New York: Palgrave Macmillan, pp. 1-27.

La'o Hamutuk. 2004. “The Special Panels for Serious Crimes - Justice for East Timor?” La'o Hamutuk Bulletin 5(3-4), October. Retrieved from https://www.laohamutuk.org/Bulletin/2004/Oct/bulletinv5n3.html

Pigou, P. 2004, April. The community reconciliation process of the Commission for Reception, Truth and Reconciliation. Retrieved from http://citeseerx.ist.psu.edu/viewdoc/download?doi=10.1.1.737.3841\&rep=rep1\& type $=$ pdf

Serious Crime Unit. No date. "About SCU." Retrieved from https://www.ocf.berkeley.edu/ changmin/Serious\%20Crimes\%20Unit\%20Files LAbout SCU.html.

Serious Crime Unit. No date. "Home." Retrieved from https://www.ocf.berkeley.edu/ changmin/Serious\%20Crimes\%20Unit\%20Files /default.html

Siboro, T. 2006, February 22. Crimes will go to trial, Timor Leste prosecutor. Retrieved from https://www.globalpolicy.org/component/content/article/163general/29218.html 
United Nations. No date. "Success in peacekeeping." Retrieved from http://www.un.org/en/peacekeeping/operations/success.shtml.

No date. UNMIT Background. Retrieved from http://www.un.org/en/peacekeeping/missions/past/unmit/background.shtml.

United Nations Peace Keeping. No date. "Terminology." Retrieved from https://peacekeeping.un.org/en/terminology.

United Nations Security Council Resolution 1272. 1999. Retrieved from https://documents-ddsny.un.org/doc/UNDOC/GEN/N99/312/77/PDF/N9931277.pdf?OpenElement.

Walby, Sylvia. 1991. Theorizing Patriarchy. Oxford: Basil Blackwell Ltd.

Wandita, G., et al. 2015, October. Enduring impunity: Women surviving atrocities in the absence of justice. Jakarta: Asia Justice and Rights.

Whitfield, T., and Griffiths, M. 2010, March. Mediation ten years on: Challenges and opportunities for peacemaking. Retrieved from http://www.hdcentre.org/wpcontent/uploads/2016/08/37Mediating10yrscropped-March-2010.pdf 